FACTA UNIVERSITATIS

Series: Law and Politics Vol. 15, No 1, 2017, pp. 37 - 44

DOI: $10.22190 /$ FULP1701037M

Review Article

\title{
CRIMINOGENIC INFLUENCE OF PENITENTIARY INSTITUTIONS
}

\author{
UDC 343.971:343.81
}

\section{Filip Mirić}

Faculty of Law, University of Niš, Republic of Serbia

\begin{abstract}
Referral to serve a sentence of imprisonment in a penitentiary institution is a very stressful experience for all convicted offenders. They are obliged to put an end to their former lifestyle and continue living in a penal institution of a closed type, governed by strict rules of conduct and featuring very diverse population of inmates. Due to the loss of freedom, many convicts are deprived of numerous privileges they used to have outside prison. In reaction to these "deprivations", they commit new crimes while serving their prison sentences. For this reason, time spent in prison can be an important criminogenic factor. In the first part of the paper, author discusses the forms of deprivation in penitentiary institutions and their impacts on prisoners' life. Then, the author points out to the criminogenic impact of the prison environment and the necessity to conduct empirical research in this area. Finally, the author underscores the need to find effective measures to reduce the criminogenic impact of the prison environment and turn penitentiaries into facilities for genuine rehabilitation and re-socialization of prisoners.
\end{abstract}

Key words: criminogenesis, deprivations, prisoners, penitentiary system.

\section{INTRODUCTORY REMARKS}

"It is said that no one truly knows a nation until one has been inside its jails. A nation should not be judged by how it treats its highest citizens, but its lowest ones."

(Nelson Mandela) ${ }^{1}$

Human rights and the rule of law largely depend on how the state and society treat the convicted offenders. Indeed, by entering the prison to serve a sentence of imprisonment, convicts start a completely new life, which is quite different from the former life outside prison. Behind the prison walls, life is limited to strict house rules and prisoners are forcibly confined to live in community with other prisoners. Yet, modern prisons should

Received January $23^{\text {rd }}, 2017$ / Accepted February $24^{\text {th }}, 2017$

Corresponding author: Filip Mirić, LL.D.

Faculty of Law, University of Niš, Republic of Serbia, Trg kralja Aleksandra 11, 18000 Niš, Republic of Serbia

E-mail: filip@prafak.ni.ac.rs

${ }^{1}$ Nelson Mandela Rules, Retrieved 23 Dec. 2016 from http://www.un.org/en/events/mandeladay/rules.shtml 
be institutions where inmates are prepared to successfully return to their life in the society. Consequently, the prison environment and the living conditions should be similar to the living conditions outside prisons. Or, is it just a utopian idea of legislators in some contemporary states? In order to talk about re-socialization of imprisoned persons, it is essential to know the "dark" side of prison life and the role of prisons in criminogenesis. The living conditions, the prisoner community and the response of the representatives of the formal penal system play the decisive role in the the process of criminogenesis in penitentiary institutions. In the author's opinion, causes of crimes committed behind the prison walls (where they should be most efficiently counteracted) should be sought in the interaction of these factors.

\section{THE CONCEPT OF PRISON DEPRIVATIONS AND THEIR IMPACT ON PRISONERS’ LIFE}

The history of penology is the most dismal chapter in the history of civilization. It portrays a human being at its worst and shows that man's cruelty, brutality and inhumanity are unlimited, regardless of time and space. Actually, absolute power over helpless people often corrupts to the core (Clark, 2009: 146). The capacity for rehabilitation and re-socialization of criminal offenders depends on the social and legal responses to crime committed by these people. In spite of the contemporary trends in penology to adjust life in prison as much as possible to the living conditions outside penal institutions, the imprisonment and deprivation of liberty has significant consequences on the psyche of the convicted person, which should be taken into account when designing treatment in penitentiary institutions.

Any denial of freedom of movement, and especially the deprivation of liberty as a criminal sanction, has some immediate and often long-term or permanent consequences on the personality of the convicted offender. Basically, this implies depriving an individual of freedom of movement and residence in a particular area, as well as the isolation from the external world, which is man's natural environment (Radoman, 2003: 230). Imprisonment and isolation in a special penal institution lead to a series of psychological consequences for prisoners. In the course of serving the sentence of imprisonment, prisoners are denied freedom of movement; they are subjected to strict institutional rules of the formal penal system; they have no influence in terms of the living conditions in the penal institution; they are separated from their family members, relatives and friends. All these circumstances deeply affect a vast majority of convicts. Many of them perceive the routine prison procedures as humiliating and demeaning: confiscation of personal belongings, taking fingerprints, hair-cutting, taking mug-shots, medical examination, assigning numbers to imprisoned convicts, entering their data in specific files and protocols. For all these reasons, convicts find themselves in a socially inferior position. In addition, prisoners are often subjected to pressure arising from two different sources: on the one hand, they are subject to the formal penitentiary system that imposes strict rules of conduct concerning life and work in the penal institution; on the other hand, they are exposed to the informal prison system, which has its own unwritten rules and "codes of conduct". Thus, there is a constant dilemma among the convicted offenders which of the two systems they should abide by (Konstantinović-Vilić, Kostić, 2011: 228), given the fact that the ultimate choice largly determines the convict's status in the penal institution. As a way of overcoming this conflict, prisoners develop different models to adapt to life in penal institutions. Johnson classified them into five groups (Radovanović, 1992: 20): 
1. "institutionalization" or "prisonisation": the convict accepts all the values and norms of prisoners' community, rejecting the moral values of the society and denying any responsibility for the criminal offense;

2. "perfect prisoner": the convict meets the requirements of the formal system and fits in all forms of treatment, fully respecting the rules of the institution;

3. "resistant convict" is characterized by a psycho-pathological personality structure; he defiantly refuses to cooperate with the staff, discards the norms of the formal system and often attacks or demonstrates aggression towards the penal institution staff;

4. "collective teasing " is a massive disparagement and ridicule of those convicts who are known or suspected to cooperate with the institution staff, usually through aggressive behavior and verbal insults;

5. "prison dependency" implies the convict's total conformity and submission to the prison system; such inmates perceive their life in prison as the dominant lifestyle and they frequently return to prison after a short stay outside the prison environment

The reaction to imprisonment and confinement to a penal institution is not the same for all convicts. It primarily depends on the structure of their personality, education, prior habits, preferences, family situation, upbringing, age, cultural, religious and other differences, the type of committed criminal activities, and the convicts' attitude toward their criminal liability. Studies have shown that the first days of stay in prison are usually crucial for the convicts' further conduct in penal institutions. First-time offenders and occasional offenders, who are imprisoned for the commission of minor or petty offences, predominantly perceive their stay in prison as a shocking experience, which is inevitably accompanied by a series of negative consequences and psychological crisis. The French penological literature specifies several psychological factors that negatively affect prisoners and lead to the emergence of defense mechanisms; these factors are: 1) a permanent constraint, duress and control of convicts leading to their seclusion/isolation, hypocrisy, duplicity, craftiness and deception; 2) the deprivation of liberty and emotional shock stemming thereof may later cause prison-related psychosis, 3) due to the daily routine of prison life and automatism of working conditions, the convicts' intellectual functions and capacities deteriorate, which often results in gradual loss of personal initiative and capacity to adapt (Konstantinović-Vilić, Kostić, 2011: 229).

A study of life in prisons has shown that convicted offenders encounter numerous frustrations, constraints and deprivations in prison environment that affect all inmates, regardless of the type of committed crime and imposed sentence. These frustrations, constraints and deprivations inevitably generate special psychological atmosphere in the prisoner community. In addition to being obliged and under pressure of the formal penitentiary system to observe the house rules, the convicts are also exposed to the the informal penitentiary system (embodied in pressure of different peer-groups); thus, the inmates encounter a dilemma whether to abide by the formal or the informal system (Kostić, Dimovski, 2013: 220).

Deprivation is defined as "taking away, denying or depriving an individual of some basic human needs, and the inability of a healthy human being to meet the basic social and instinctual needs" (Konstantinović-Vilić, Kostić, 2006: 221). Psychological atmosphere is not the same in all prisons. It primarily depends on the level of security in prison themselves. Maximum security prisons are generally considered to be "harsh" because of the very strict rules of conduct in prison life. Therefore, the level of convicts' exposure to deprivation is inversely proportional to the degree of security. There are five different forms of deprivation: deprivation of liberty, deprivation of material goods and services, deprivation of heterosexual relations, deprivation of personal autonomy, and deprivation security. 
Deprivation of liberty is the most important form of deprivation which affects all inmates regardless of the length of imposed sentence and type of committed crime. It has a dual impact: first, the convicted offenders are imprisoned in a specific penal institution and isolated from the outside world; second, the inmates' freedom of movement is restricted within the institution itself. In prison, convicts live a routine life, according to a strictly regulated pattern, which reduces all of them to the physical status of minors who are deprived of initiative or possibility to manage their own lives as they wish. Hence, for a vast majority of convicts, it is very difficult to accept not only the loss of freedom but also the fact that they have been rejected by society (Konstantinović-Vilić, Kostić, 2011:229-230).

Deprivation of material goods and services is the inability to hold and enjoy all those material goods and services that prisoners had at their disposal before coming to prison. Life in prison is designed to provide for meeting only the basic living needs (in terms of food, clothing, health care, etc.). Given the fact that convicts are unable to hold personal items that often serve as status symbols, it is a source of many frustrations and psychological crisis. To compensate for this deprivation, convicts keep completely harmless items in their personal lockers, which is often contrary to the house rules. However, many convicts resort to trading with items whose use is generally prohibited in prisons (mobile phones, drugs, etc.); thus, despite the risk of being penalized by the formal penal system, they overcome the effect of this deprivation (Konstantinović-Vilić, Kostić, 2011:230).

Deprivation of heterosexual relationship stems from a very important features of penitentiary institutions: the fact that they house prisoners of the same sex. When it comes to this form of deprivation, there are two basic problems: the extent of sexual frustration experienced by prisoners, and how they behave in the prison environment in which they were deprived of heterosexual relationships. This deprivation occurs in male and female prisons alike, and it is considered one of the strongest deprivations in the prison environment. Its effect on the convicts'psychic life of is even stronger in such environment because it is not seen only as an inability to satisfy one's sexual instincts but also as an inability to establish normal intersexual emotional relationships. Thus, the convicts' sexual frustrations are often the source of their aggressive behavior. There are two basic ways to overcome this frustration: a) the erotic stimulus through pornographic material, which is procured through illegal channels in violation of applicable prison regulations; and b) the emergence of homosexual relationships. It is believed that homosexuality in women's prisons occurs as a result of the prisoners' desire to regain the lost role in society; in contrast, homosexuality in male prisons occurs as a result of the inability to satisfy sexual instincts in some other way (Konstantinović-Vilić, Kostić, 2011:230-231).

Deprivation of personal autonomy occurs because the prisoners are forced to comply with strict prison rules and orders. The inmates' behavior is strictly controlled and determined by the house rules and other institution rules. There are opinions that strict control over the convicts' behavior is very useful as it prevents the emergence of deviant and delinquent behavior. Conversely, the most common objection to such viewpoints is that excessive control of convicts' behavior in their daily activities (dressing, eating or personal hygiene) reduces them to the level of a child and restricts their autonomy, which can eventually lead to aggressive behavior and strengthening of the informal prison system alongside the formal one. The degree of loss of autonomy depends on the level of security in prisons, and it is much higher in closed-type prisons than in semi-open and open-type prisons. Moreover, the convicts' reactions to the deprivation of autonomy are not the same, ranging from mild depression to aggression and deep depression. Above all, 
a more extensive deprivation of autonomy also leads to strengthening of informal peer groups within the prisoner community, through which inmates try to minimize and mitigate the effects of this form of deprivation (Konstantinović-Vilić, Kostić, 2011: 232).

Deprivation of security comes as a result of the communal system of serving the sentence in the prison community with other convicted offenders. Living with other prisoners is not easy; life in prison is often full of danger and even the "boldest" and the "most prominent" prisoners often fear for their safety and lives. Each informal group of prisoners tends to impose its own "code" of conduct on other convicts, which is often the reason for open conflict. The actual effect of the deprivation of security is best reflected in the proverbial saying: "Serving time in prison may not be as harsh as the incarcerated prisoners themselves". As they are often in a position to choose between the formal system (which is unable to provide absolute security in prisons) and informal groups that impose their own rules, many prisoners are inclined to join groups with which they share the same or similar values (Konstantinović-Vilić, Kostić, 2011: 232).

The convict's negative reactions to all these forms of deprivation can lead to their asocial or antisocial behavior. For this reason, the living conditions and relationships in penitentiary institutions may be of importance for the genesis of crimes in prisons, which will be discussed further on in this paper.

\section{PRISON - A PATH TO RE-SOCIALIZATION OR RECIDIVISM?}

Life in prison embodies two basic types of relations: the relationship between the prisoners and the representatives of the formal system, and relationships among the convicted offenders. Life in prison is often boring and reduced to daily routine; it takes place under strictly defined institutional rules that do not leave much space for the expression of personal preferences and pro-social aspirations. In such circumstances, many young convicts become "easy targets" of professional criminals, for which reason prisons are nowadays considered to be "school of crime" rather than places for true rehabilitation and re-socialization of imprisoned persons (who were deprived of their liberty by a final court decision). As a matter of fact, it can be said that the prison environment engenders a negative kind of socialization, which is completely contrary to the goals of treatment aimed at re-socialization of convicts and preparing them to successfully return to community life after serving their sentences. The essence of combating crime in prisons is to suppress the negative socialization of convicted offenders. To counter this problem in the right way, it is necessary to analyze all those factors that lead to commission of crime in penitentiary institutions. These factors will be discussed in the next part of this paper.

As already noted, serving a sentence in penitentiary institutions can be a criminogenic factor. This does not necessarily apply only to time spent in prison but also to the conditions and specificity of life in prison environment. Poor punitive treatment, which is aimed at eliminating the causes of the commission of offenses, creates the possibility of recidivism in the course of serving the sentence of imprisonment. In prison conditions, time passes slowly; thus, if the convicts' spare time is not filled with adequate contents, many crimes in prisons may be committed as a result of idleness at times of leisure ${ }^{2}$.

\footnotetext{
${ }^{2}$ For the study of life in prisons and Serbia is of great importance and shows are shot in numerous series, which were aimed at fair presentation of life convicts in penitentiary conditions. Series "Dossier prison" which was broadcast on Radio Television Serbia in 2006 stands out between many similar series.
} 
The main problem in the treatment of convicts in Serbia today is that they are subject to standardized forms of treatment which leave no space for adapting the treatment to the prisoners' individual needs. Moreover, there is a highly likelihood of "criminal contagion", which rests on the hypothesis that criminal behavior is contagious. Thus, for many convicts, time spent in prison is a chance to gain new criminal experience, to upgrade their criminal skills, to network and expand the circle of friends from the criminal environment, to develop and sustain the prisoners' code of conduct through a number of unwritten principles and rules aimed at strengthening the informal prison system. While serving their prison sentence, convicts encounter numerous deprivations, criminal infestation, prison overcrowding; in such circumstances, they either fight for their status in a group or succumb to the superior power (in line with the proverb "might makes right"); moreover, they have to fight boredom, inactivity, lack of engagement in meaningful work, a limited choice of activities to fill their spare time, and other similar problems (Macanović, 2016).

The criminogenic effect on penitentiary institutions is usually reflected in "criminal infestation", the process through which criminal experience and skills are transferred from highly experienced criminal offenders to less experienced prisoners. Thus, instead of being institutions for re-socialization of convicted offenders, prisons are increasingly turning into "schools of crime". This process is similar to the process which takes place in the criminal groups outside prisons, where individual criminals and antisocial individuals manage to indoctrinate others with their own value system and transformed them into attitudes and norms of the entire group (Milutinović 1988: 225). One of the major factors that influence the occurrence of crime in prisons and other penal institutions is the length of time spent there. The longer one stays in prison longer, the greater the impact and the negative consequences of the prison culture, particularly if these effects are not removed by relevant preventive measures and adequate therapeutic treatment (Milutinović 1988: 226). In case of "prisonisation", the convict is full institutionalized, which leads to the erosion of personality and inability to adapt to life outside the penitentiary institution.

From all the above, it may be wrongly assumed that contemporary penitentiary institutions cannot respond to their primary mission and should be abolished, which is certainly not true. When it comes to the criminogenic impact of the prison environment on the commission of crime, penal institutions should find effective mechanisms to suppress these negative trends. One of these mechanisms is certainly providing the opportunity for convicts to work during their stay in prison, as a form of working therapy/treatment. As a positive example of this approach, we note the opening of a new textile facility (drive) on the premises of the Correctional Facility in Nis in 2016. This facility will employ 180 convicts, who will be working in three shifts. ${ }^{3}$ Many of the products that we use every day (such as laundry, furniture, clothing and footwear) can be produced by convicts ${ }^{4}$. Raising awareness about the importance and social utility of convicts' work in the wider community can reduce the stigmatization faced by almost every convicted person after serving his prison sentence. Therefore, the conjunction of labor, vocational training, education and other forms of treatment should be considered as effective means of combating the criminogenic influence in penitentiary institutions.

\footnotetext{
${ }^{3} \mathrm{U}$ zatvoru otvoren novi tekstilni pogon (New textile manufacture opened in prison), 2016, Retrieved 14.11. 2016 from http://www.novosti.rs/vesti/srbija.73.html:631570-Nis-U-zatvoru-otvoren-novi-tekstilni-pogon).

${ }^{4} 11$ Products You Might Not Realize Were Made by Prisoners,(2013); Retrieved 14 November 2016, from http://mentalfloss.com/article/51037/11-products-you-might-not-realize-were-made-prisoners .
} 


\section{CONCLUDING REMARKS}

Confinement to serve a sentence of imprisonment in a penitentiary institution is a major stress for each convict. At the moment, many of them seem to leave their former life, habits, hopes and expectations outside the prison walls. From that perspective, we can conclude that prisons are ludicrous institutions because inmates have to be socialized by being separated from the society. Of course, this is not true because prisoners are confined to prisons in order to correct their behavior and value system. Unfortunately, during their stay in penal institutions, prisoners are subjected to a number of negative effects of deprivation, the most apparent and important of which is the deprivation of freedom. In such circumstances, the informal prison system develops as a way to overcome and reduce the negative effects of different forms of deprivation. However, it also gives rise to "criminal contamination", which reflects the criminogenic impact of penitentiary institutions.

How to prevent criminogenesis in penal institutions which are essentially envisaged, according to the letter of the law, to serve for the re-socialization of convicted offenders? What can be done to prevent further 'criminal infestation' in prisons? The answers to these questions are much more complex than it appears at first sight. The ultimate solutions to these problems may be sought in strengthening the effectiveness of prisoner treatment (primarily through inmates' labor and education), as well as strengthening the links between the prisoners and the wider community. The idea of inmates' re-socialization will remain alive only when we realize that prisoners are not people who should be isolated from and rejected by the society. Only when we truly start believing in the concept of resocialization, penal institutions will successfully accomplish their primary mission: to empower the inmates who served their sentence to return to the society, carry on with their lives and be useful members of the community.

\section{REFERENCES}

Klark, R. (2009) Kriminalitet u Americi (Crime in America), Beograd: Pravni fakultet u Beogradu.

Konstantinović-Vilić, S.; Kostić, M. (2011) Penologija (Penology), Niš: Centar za publikacije Pravnog fakulteta u Nišu.

Konstantinović-Vilić, S.; Kostić, M. (2006) Penologija (Penology), Niš: Sven.

Kostić, M; Dimovski, D. (2013) Osuđeničke bande u Sjedinjenim Američkim Državama (Prison Gangs in the United States), Zbornik radova Pravnog fakulteta Univerziteta u Nišu, vol. 65, pp. 219-236.

Macanović, N. (2016) Zatvori kao kriminalni fakulteti (Prisons as faculties of crime), Retrieved 14 Nov, 2016 from http://www.humanusbalkanika.com/zatvori-kao-kriminalni-fakulteti/

Milutinović, M. (1988) Penologija (Penology), Beograd: Savremena administracija.

Nelson Mandela Rules, Retrieved 23 Dec. 2016, http://www.un.org/en/events/mandeladay/rules.shtml

Radovanović, D. (1992) Čovek i zatvor-studija integrisanosti u zatvorenički društveni sistem (Human and prison- study of integration in prisoners' social system), Beograd:Prometej.

Radoman, M. (2003) Penologija i sistem izvršenja krivičnih sankcija (Penology and system of enforcement of criminal sanctions), Novi Sad - Beograd: Pravni fakultet u Novom Sadu, Centar za izdavačku delatnost.

U zatvoru otvoren novi tekstilni pogon (New textile manufacture opened in prison) (2016), Retrieved 14 Nov, 2016 from http://www.novosti.rs/vesti/srbija.73.html:631570-Nis-U-zatvoru-otvoren-novi-tekstilni-pogon .

11 Products You Might Not Realize Were Made by Prisoners (2013), Retrieved 14 Nov, 2016, from http://mentalfloss.com/article/51037/11-products-you-might-not-realize-were-made-prisoners. 


\section{KRIMINOGENI UTICAJ PENITENCIJARNIH USTANOVA}

Upućivanje na izdržavanje kazne zatvora za svakog osuđenika je veoma stresno. Prekida se dotadašnji način života $i$ život nastavlja u ustanovi zatvorenog tipa u kojoj postoje stroga pravila ponašanja, među veoma heterogenom populacijom. Usled gubitka slobode kod mnogih osuđenika može doći do pojave niza deprivacija $i$ kao reakcija na njih do izvršenja novih krivičnih dela tokom izdržavanja kazne zatvora. Zbog toga i sam boravak u penitencijarnim ustanovama može predstavati izražen kriminogeni faktor. U prvom delu rada su analizirane deprivacije u penitencijarnim ustanovama i njihov uticj na život osuđenika, da bi se zatim ukazalo na kriminogeni značaj samih penitencijarnih ustanova $i$ na neophodnost empirijskih istraživanja u ovoj oblasti. Pronalaženjem efikasnih mera za smanjivanje kriminogenog uticaja penitencijarnih ustanova, one će postati mesto za istinsku i suštinsku resocijalizaciju oduđenika.

Ključne reči: kriminogeneza, deprivacije, osuđenici, penitencijarni sistem 